\title{
ОСНОВНІ МЕТОДИЧНІ ЗАСАДИ ФОРМУВАННЯ ПОВНОЦІННИХ ФАХІВЦІВ НОВОГО ЧАСУ
}

\author{
Чава Г. Ф. \\ викладач англійської мови \\ Нікопольський коледж \\ Дніпровського державного аграрно-економічного університету \\ вул. Патріотів України, 167, Нікополь, Дніпропетровська область, Україна \\ orcid.org/0000-0001-5083-7229 \\ anna.chava411@gmail.com
}

Народовська О. М.

викладач англійської мови кафедри англійської мови гуманітарного спрямування № 3

Національний технічний університет України

«Київський політехнічний інститут імені Ігоря Сікорського»

пр. Перемоги, 37, Київ, Украӥна

orcid.org/0000-0002-9869-1764

kpiteacherenglish@gmail.com

Ключові слова: професійна підготовка, розум, інтелект, мислення, емоційний інтелект, критичне мислення.
Дана стаття присвячена розгляду явища критичного мислення й емоційного інтелекту та вказує на принципові показники важливості впровадження системної методичної роботи в освітніх закладах за цими напрямками, адже випускники закладів вищої та професійної освіти майбутні професіонали, які мають володіти здатністю вирішувати важливі робочі та особисті питання в різних умовах. Ефективність діяльності 3 розвитку емоційного інтелекту залежить від створення психологічних та певних емоційних умов під час навчання. Викладачам необхідно не лише визначити рівень інтелектуальних здібностей та розвивати ïx, а й формувати вміння адаптуватись та взаємодіяти у суспільному та професійному середовищі. Фахівці, які мають досить розвинений емоційний інтелект самодисципліновані, легше пристосовуються до нових умов та швидше просуваються кар'єрними сходами.

Також наводиться ряд аргументів із важливості формування зазначених вище вмінь у майбутніх фахівців на практичній основі, адже у професійній самосвідомості студентів емоційний інтелект має вагоме значення. Необхідність його розвитку продиктована потребою у рефлексії $\mathrm{i}$, як наслідок, здатністю розуміти не лише власні емоції, а й емоції оточуючих. Таким чином, майбутній спеціаліст набуває вміння об'єктивно оцінювати як власну, так і професійну діяльність своїх колег та опонентів.

Емоційний інтелект $\epsilon$ важливою складовою частиною формування висококваліфікованих фахівців, яку можна розвивати впродовж всього періоду навчання. Даний феномен не можна розглядати окремо від пізнавальної діяльності студентів, оскільки освіта передбачає цілісність емоційної та інтелектуальної сфер розвитку особистості. Отже, поняття емоційного інтелекту має розглядатись невідривно від понять «розум» та «мислення». За таких умов можливо сформувати особистість, яка здатна адаптуватись до сучасних тенденцій розвитку світу, адже фахівці 3 високим рівнем розвитку емоційного інтелекту володіють гарними навичками спілкування, впевнені в умовах виникнення кризових ситуацій та успішні у вирішенні конфліктів як професійно важливих, так і тих, що пов'язані з особливостями взаємовідносин у суспільстві. 


\title{
BASIC METHODOLOGICAL BACKGROUND OF FORMING A NEW GERERATION SPECIALIST
}

\author{
Chava H. F. \\ English Teacher \\ Nikopol College \\ of Dnipro State Agrarian and Economic University \\ Patriotiv Ukrainy str., 167, Nikopol, Ukraine \\ orcid.org/0000-0001-5083-7229 \\ anna.chava411@gmail.com
}

\author{
Narodovska O. M. \\ Lecturer of English Language at the Department of English for Humanities № 3 \\ National Technical University of Ukraine "Igor Sikorsky Kyiv Polytechnic Institute" \\ Peremogy ave., 37, Kyiv, Ukraine \\ orcid.org/0000-0002-9869-1764 \\ kpiteacherenglish@gmail.com
}

Key words: professional training, mind, intelligence, thinking, emotional intelligence, critical thinking.
This article is devoted to the phenomenon of critical thinking and emotional intelligence and points to the fundamental indicators of the importance of implementing systematic methodological work in educational institutions in these areas, because graduates of higher and professional education are future professionals who must have the ability to solve important work and personal issues in different conditions. The effectiveness of emotional intelligence depends on the creation of psychological and certain emotional conditions during learning. Teachers need not only to determine the level of intellectual abilities and develop them, but also to develop the ability to adapt and interact in the social and professional environment. Professionals who have a well-developed emotional intelligence are self-disciplined, easier to adapt to new conditions and move up the career ladder faster.

There are also a number of arguments on the importance of forming the above skills in future professionals on a practical basis, because in the professional selfconsciousness of students, emotional intelligence is important. The need for its development is dictated by the need for reflection and, as a consequence, the ability to understand not only their own emotions, but also the emotions of others. Thus, the future specialist acquires the ability to objectively assess both their own and professional activities of their colleagues and opponents.

Emotional intelligence is an important component of the formation of highly qualified professionals, which can be developed throughout the training period. This phenomenon cannot be considered separately from the cognitive activity of students, as education involves the integrity of the emotional and intellectual spheres of personality development. Thus, the concept of emotional intelligence should be considered inseparable from the concepts of mind and thinking. Under such conditions, it is possible to form a person who is able to adapt to current trends in the world, because professionals with a high level of emotional intelligence have good communication skills, confident in crisis situations and successful in resolving conflicts both professionally important and emerging. associated with the peculiarities of relationships in society.
Постановка проблеми. У статті розглянуто проблему розвитку емоційного інтелекту майбутніх випускників закладів вищої освіти, адже їх професійна успішність безсумнівно пов'язана 3 рівнем знань, умінь та навичок, здобутих під час навчання, а також 3 ерудицією та здатністю до мислення, тобто з рівнем загального інтелекту. Проте в більшості випадків високого рівня інтелектуального розвитку є недостатньо, що свідчить про необхідність розвитку емоційного інтелекту. 
Даний феномен, у свою чергу, поєднує здатність особистості до ефективного спілкування за рахунок емпатії, а також вміння підлаштовуватись під емоційний стан оточуючих.

Актуальність цього дослідження зумовлена швидким впровадженням все більшої частки «машинної» роботи для виконання ряду професійних задач, що в свою чергу, зменшує номінальну цінність основних професійних навиків та підвищує значущість вміння активно та ефективно здійснювати особисту інтерперсональну комунікацію, взаємодіяти 3 колегами у колективі та 3 клієнтами (споживачами) на підприємстві.

Таким чином, буде розглянуто чинники у розумовій діяльності студентів, що мають найбільш значущий вплив на результативність їх майбутньої професійної діяльності. Та розглянуто практичний вплив розвиненого емоційного інтелекту на професійну успішність молодого фахівця.

Метою статті $\epsilon$ провести теоретичний аналіз та узагальнити інформацію з проблеми умов та засобів розвитку емоційного інтелекту у випускників закладів вищої освіти.

Тому для формування ефективної методики підготовки майбутніх фахівців $\epsilon$ важливою обізнаність у принципах формування мислення на кожному етапі та розгляд схеми та шкали оцінювання їх доцільності та визначення впливу перебігу останніх на якість кваліфікації працівника.

Ця робота допоможе з'ясувати різницю між розумною, інтелектуальною та мислячою людиною та допоможе сформувати більш чіткі напрямки, які необхідні саме для професійної діяльності.

Виклад основного матеріалу дослідження. Довгий час більшість представників науки чітко розмежовували емоційні та інтелектуальні напрямки розвитку особистості, а відповідно формування професіоналів та фахівців своєї справи передбачало саме розумову діяльність та інтелектуальну формацію, що, у свою чергу, відділяло таке поняття як емоційний інтелект від загального пласту професійної освіти.

Психіка розкриває себе через психічні процеси, психічні стани, психічні властивості особистості. Таким чином ключовим було бачення відмінностей між пізнавальними, емоційними і регулятивними психічними процесами. У результаті дії пізнавальних процесів ми отримуємо уявлення про властивості зовнішнього середовища. До тих пір, поки існує людина, вона не може не намагатися зрозуміти навколишній світ і самого себе. Це необхідна умова людського життя, діяльності та комунікації [11]. Таке розуміння забезпечується здоровим глуздом, а також ресурсами повсякденної мови і певної культури. Особливе визнання конструктивізм отримав у науках про людину: психології, історії, соціології, що внесло суттєві поправки в розвиток методології підготовки майбутніх спеціалістів за даними направленнями. Водночас повноцінне професійне функціонування спеціаліста в умовах прискореного розвитку віртуальних програм та штучного інтелекту як невід'ємної складової частини успішного підприємництва та засобу комунікації, ставить перед професіоналами нового покоління більше інтелектуальних вимог, що базуються саме на емоційному підгрунті. На сьогодні це єдина складова частина, яку не в змозі замінити машинна частина [16].

Слова відомого філософа Е. Гуссерля про те, що здоров'я і істинність європейської духовності залежить від функціонуючого мозку, говорять нам не лише про загальний розвиток особистості чи то суспільства, а й $є$ головними аспектами розвитку професіоналів. Зазначений автор також був стурбований тим, щоб повернути темі розуму статус незалежної духовної інстанції, що взяла на себе сміливість судити про світ об'єктивно. Він писав про те, що небезпечно і згубно обмежувати вивчення розуму сферою техніко-прагматичних додатків [6]. Саме тут, в прикладних сферах відступ від стандартів раціональності часто стає, на його думку, методологічною умовою отримання шуканої інформації. Включаючись в рішення прикладних пізнавальних завдань (будь то у сфері природних або гуманітарних технологій), людина втрачає мотивацію, що орієнтує іiї на об'єктивне і раціональне пізнання як таке [5], що, у свою чергу, призводить до необ'єктивного бачення ситуації в рамках професійної діяльності. Такі процеси деформують основи для таких вагомих навичок, як медіація та швидке вирішення конфліктних ситуацій, робота в команді, надання пріоритетів у виконанні завдань та критичне мислення в процесі пошуку нових підходів до виконання завдань. Відповідно, розум $є$ першим основоположним щаблем для формування свідомості та навичок майбутніх фахівців.

$€$ підстави вважати, що широта когнітивних досліджень у наші дні певною мірою пов'язана і 3 виданням праць видатного російського філософа Г.Г. Шпета, арсенал евристичних ідей якого неосяжний. Вчений, зокрема, розмірковує про розмежування завдань логіки і психології. Обидві дисципліни користуються судженням. Задається питання: чи не тотожні логіка і психологія в пізнанні? Справедливими $\epsilon$ зауваження російського філософа про те, що психологія, поряд із правильним мисленням, повинна, звичайно, вивчати і неправильне мислення. Г.Г. Шпет критикує звичайні заперечення проти психологізму в логіці: «Отже, в логіки $\epsilon$ свій особливий самостійний об'єкт, абсолютно незалежний і неоднорідний з об'єктом психології, 
отже, існування логіки $є$ необхідним» [17]. На фоні даного твердження формується підстава вважати поняття «емоційний інтелект» більш ширшим за поняття, що обмежуються лише логікою. Адже фахівець, який керується логікою? буде раціональним, оскільки за засадами логічного мислення буде обирати лише правильні та раціональні варіанти до впровадження. Спеціаліст із розвиненим «емоційним інтелектом» керуватиметься варіантами 3 похибками та враховуватиме можливі ризиковані та програшні аспекти, що підвищить ефективність та функціональність прийнятого рішення.

Спираючись на вищенаведені дослідження, варто відзначити, що повноцінно розвинена розумова діяльність окремого індивіда не забезпечує його професійну функціональність. Тобто навіть за умови оволодіння здобувачем освіти повним обсягом теоретичних знань, що веде до ерудованості у професійній сфері й демонструє розвинений навик пізнання, важко назвати такого робітника в майбутньому висококваліфікованим, а тим паче ефективним. Тому що не можна говорити про пізнання, якщо воно ні на що не направлене, а логіка, як питання залишиться назавжди. Таким чином, відношення між логікою і пізнанням не $\epsilon$ відношенням підпорядкованості або координації, a $\epsilon$ ставленням протилежностей. Тому для формування висококваліфікованих та ефективних у практичній діяльності молодих фахівців варто йти далі: розум - інтелект - мислення.

На цьому етапі варто розглянути кожен структурний елемент окремо.

Розум - первинний щабель розумної діяльності, вихідний рівень мислення, що обмежує оперування абстракціями заданими схемою. Можна охарактеризувати розум як психічну діяльність, що, утворюючи поняття судження, умовиводи, постачає цим матеріалом мозок.

Розум - це людська можливість послідовно і ясно міркувати, піддавати класифікації явища. I. Кант запропонував переконливе розрізнення двох рівнів розумової діяльності: «Будь-яке наше знання починається 3 почуттів, переходить до розуму і закінчується в розумі, вище якого немає в нас нічого для обробки матеріалу споглядань і для підведення його під вищу єдність мислення» [1].

Iнтелект (від лат. - розуміння, осягнення) у психології визначається як загальна здатність до пізнання і вирішення проблем, що впливає на успішність будь-якої діяльності і лежить в основі інших здібностей. Інтелект не зводиться до мислення, хоча саме розумові здібності складають його основу.

Загалом інтелект - це система всіх пізнавальних здібностей людини: відчуття, сприйняття, пам'яті, уявлення, уяви і мислення. Поняття інтелекту як загальної розумової здібності застосовується в якості узагальнення поведінкових харак- теристик, пов'язаних з успішною адаптацією до нових життєвих завдань.

У зв'язку із цим у психології з'явився термін «хороший інтелект», тобто інтелектуальні здібності, які знаходять втілення в реальному житті людини і сприяють його високим соціальним досягненням.

Поява тестів на інтелект поставила ряд дослідницьких проблем. Зокрема, стало важливим визначити, які саме показники та за якою шкалою демонструють найкращих представників до розумової та професійної чи то кваліфікованої діяльності. Одна з них - структура інтелектуальних здібностей. У психології склалися два основних напрямки досліджень у цій області. Перший напрям представлено авторами, які розглядають інтелект як набір відносно незалежних розумових здібностей. Так, Л. Терстоун розробив мультифакторну модель інтелекту [9], згідно з якою існує ряд відносно незалежних розумових здібностей. Але найбільш впливовою і популярною $є$ факторна модель Дж. Гілфорда, який виділив три способи «вимірювання інтелекту»:

1) розумові операції;

2) особливості матеріалу, що використовується у тестах;

3) отриманий інтелектуальний продукт.

Поєднання цих елементів («куб» Гілфорда) дає 120 інтелектуальних факторів, частину з яких вдалося ідентифікувати в емпіричних дослідженнях. Заслугою Гілфорда вважається виділення «соціального інтелекту» як сукупності інтелектуальних здібностей, що визначають успішність оцінки і прогнозування поведінки людей [3].

Інший напрямок базується на ідеї наявності загального фактора інтелекту, визначає специфіку і продуктивність всієї інтелектуальної діяльності людини. Основоположником цього підходу $є$ Ч. Спірмен. Він висунув концепцію «генерального фактора» - $G$ (general factor), розглядаючи інтелект як загальну «розумову енергію», рівень якої визначає успішність і продуктивність всієї інтелектуальної діяльності. Рішення будь-якої конкретної задачі залежить від розвитку у людини здібності, пов'язаної з фактором G, від набору специфічних здібностей, необхідних для вирішення вузького класу задач. Ці спеціальні здібності мають у Спірмена назву $S$-факторів (від англ. special-cпеиіальний).

Майже через 80 років після появи перших тестів на визначення інтелекту у 1983 р. Говард Гарднер поставив під сумнів концепцію тестового IQ виміру інтелектуальних здібностей Альфреда Біне. Г. Гарднер висунув теорію його множинності (TMI по багатьох позиціях являється діаметрально протилежною концепції Ай-Кью (IQ), якою прагнув, подолавши межі результатів тесту 
на інтелект, розширити діапазон інтелектуального потенціалу людини. Його концепція на серйозному рівні бере до уваги багатогранність поглядів на інтелект. Така модель частково базована на наукових шуканнях, що навіть не існували в часи Біне: когнітивна наука (вивчення мислення) та нейронаука (вивчення мозку) [1].

Гарднер визначив 7 видів інтелекту: музичний, тілесно-кінесичний, логіко-математичний, лінгвістичний, просторовий, міжособистісний та внутрішньо-особистісний. «.... існує, якнайменше, декілька видів інтелекту, вони відносно незалежні один від одного, вони можуть проявлятися та поєднуватися багатьма шляхами» [4].

Основними концептуальними положеннями Г. Гарднера $є$ такі:

- інтелект неможливо виміряти в лабораторних, штучних умовах шляхом виконання якихнебудь тестів (в тому числі і тесту Ай-Кью);

- категорично не виправдано пояснення расових i релігійних відмінностей, базуючись на результатах тестів які вимірюють інтелект (як це роблять прибічники теорії Ай-Кью);

- інтелект людини не однозначний, він - множинний.

Теорія Г. Гарднера спирається на фундаментальні нейрофізіологічні і психологічні дослідження. Прибічники Ай-Кью вважають, що інтелект даної конкретної людини визначений, фіксований і статичний. Тобто інтелект в їхньому розумінні це те, з чим людина народжується і що не змінюється протягом всього іiі життя. Однак дослідження прогресивних нейропсихологів доводять зовсім протилежне - інтелект може змінюватись і розвиватись в процесі навчання. Г. Гарднер стверджує, що інтелект людини може не просто удосконалюватись, а й розвиватись як мінімум по семи напрямах. Докладний розгляд кожного напряму та визначення інтелекту можна знайти в книзі «Будова розуму» (1983).

Під інтелектом Г. Гарднер розуміє неординарну здібність людини до нестандартного вирішення проблем; генерації нових проблем та ідей; створення продукту або надання послуг, що наділені високою ступінню цінності в даній культурі.

Безперечно, що у різних людей ті чи інші здібності розвиваються по-різному: одні володіють універсальними інтелектуальними здібностями, інші проявляють свій інтелект в якійсь одній вузькій області. Так, наприклад, відомий геній Ібн Сіна (Авіценна) був одночасно і філософом, і лікарем, і поетом, і автором трактату по теорії музики. $\Phi$. Гаусс - мав неординарні інтелектуальні здібності в одній області - математиці. Багато 3 нас, простих пересічних індивідуумів, знаходяться в середині між вказаними вище полярними полюсами розвитку людського інтелекту [2; 3].
Таким чином, для роботи зі студентами - майбутніми професіоналами, важливо не лише з'ясувати їх схильності до розумової діяльності, виділити інтелектуальні здібності та допомогти із розвитком наявних. Необхідно формувати вміння взаємодіяти із представниками інших направлень та вивести універсальне вміння адаптації та взаємодії у суспільному та професійному середовищі. Саме тут на допомогу приходить «емоційний інтелект».

Емоиійний інтелект - це вміння дати раду своїм і чужим емоціям: точно зрозуміти, оцінити і виразити їх.

У загальному розумінні емоційний інтелект (EI) розглядається як здатність працювати 3 емоціями і проявляти емпатію. Сюди відноситься вміння розпізнавати емоції, визнавати негативні i позитивні почуття, відокремлювати особисте сприйняття від наочних фактів, управляти власними і чужими емоціями. Це певна людська здатність до дуже точного відчуття ситуації, розуміння бажань оточуючих, стійкості до стресу і впливу негативних емоцій.

Серйозну наукову розробку теорія емоційного інтелекту отримала в 90-х роках 20 століття в роботах американських вчених: Д. Карузо, П. Селовейя, Дж. Майєра [14]. Вони розділили емоційний інтелект на 4 складові частини:

1) вміння визначати свої і чужі емоції, знаходити відмінності між ними;

2) вміння задіяти весь потенціал емоцій для вирішення конкретних завдань;

3) здатність усвідомлювати кожну емоцію i розуміти, як вона виникає;

4) вміння контролювати свої емоції і керувати ними.

Цю модель ЕI спочатку взяли в роботу представники сфери бізнесу і економіки, віддаючи на обробку і реалізацію керівникам великих компаній.

Існує і ряд інших теоретичних моделей емоційного інтелекту, але в основі вони мають схожі положення. Говорячи про застосування EI в особистому і соціальному житті, сучасні психологи, узагальнюючи матеріал, представляють його у вигляді набору навичок 4-ох категорій:

- здатність прозоро і зрозуміло спілкуватися 3 людьми, вміти уважно слухати, висловлювати свої думки і очікування від співрозмовників, працювати в команді і ефективно ії очолювати;

- вміння проявляти емпатію і відчувати себе в будь-якій компанії «як риба у воді»;

- певне знання себе - особистих недоліків i переваг, адекватне їх сприйняття і вміння вибудовувати свій життєвий план на основі цього;

- майстерність керувати своїми емоціями, не допускати їх деструктивного впливу на власне життя, 
вміння «підлаштовуватися» під загальне середовище і зберігати міцні і тривалі відносини з людьми.

Отже, емоційний інтелект - це так звана «повітряна подушка», що в будь-якій ситуації втримає людину «на плаву». Він допомагає максимально активізувати свої ресурси в разі кризової життєвої ситуації, налаштувати систему дружніх і відкритих взаємин з оточуючими людьми, уникнути згубного впливу стресу.

Останньою складовою частиною у формуванні молодого фахівця є вміння мислити. Уміння мислити є провідною здібністю, необхідною для виживання у майбутньому. Фахівці різних галузей у цьому разюче одностайні. XXI ст. стане часом, коли саме розумові здібності окремих людей, а не природні ресурси, капітал і технології визначатимуть вирішальну грань між успіхом і невдачею, між лідерами та веденими. Саме уміння мислити забезпечує науково-технічний і суспільний прогрес та є запорукою демократії. Цей факт визнається всіма: 1 філософами, і економістами, і педагогами. Ларошфуко свого часу дотепно зауважив: «Всі скаржаться на власну пам'ять, але ніхто на свій розум». Таким чином, гарне мислення - це життєво важлива навичка, яку слід розвивати й удосконалювати в майбутніх фахівців. Але що означає розвивати мислення? Аби відповісти на це запитання, спочатку з'ясуємо, які прояви має мислення.

Виділяють два основні прояви мислення:

- відображення оточуючого світу, внаслідок чого формуються поняття;

- розв'язання проблем (задач), внаслідок чого отримуємо розв'язану задачу й доцільну дію.

Отже, розвивати мислення можливо лише шляхом опанування наукових понять та шляхом розв'язування проблемних задач. Взагалі-то, мислення це не що інше як розв'язування різноманітних задач. Відправним пунктом активного розумового процесу є проблемна ситуація - конфлікт між тим, що дано людині, і тим, чого вона прагне досягти. У цьому розумінні про справжнє мислення можна говорити як про творчість, коли у людини $є$ задача зі сформульованою метою, проте відсутні засоби їі досягнення. Між іншим, інколи формулювання мети може стати самостійною проблемою. Проблемна ситуація - поняття суб'єктивне. Те, що є проблемою для одного, для іншого може такою й не бути. Ситуація тоді стає проблемною, коли людина сприймає іiі як проблему (утруднення). Наступним кроком є усвідомлення проблеми як особисто значущої, важливої, цікавої. Лише в такому випадку можливо відшукати шляхи іii розв'язання. Таким чином розвиток інтелекту попередньо є не менш значущим та основним для подібного виду діяльності [18].

Процес мислення - це складне, неоднорідне і багаторівневе явище, яке по-різному проявляється в різних ситуаціях. Види мислення диференціюють за певними ознаками. Нас цікавитимуть два види мислення: творче i критичне. Творче мислення спрямоване на створення нових ідей, а критичне виявляє сильні та слабкі сторони цих ідей, оцінює їх корисність. Для того, аби розв’язати проблемну задачу потрібні два види мислення, хоча використовуються вони почергово. Щоб побудувати гіпотези потрібне творче мислення. А для того, щоб перевірити їх, у пригоді стане критичне мислення, адже не будь яка гіпотеза є правильною.

Саме на даному етапі стає в нагоді розвинений емоційний інтелект. У процесі критичного осмислення нової творчої концепції розглядається не лише причинно-наслідковий алгоритм апробації виведеного проблемного питання 3 приводу успішності задуманого, а також враховується загальне ставлення оточуючих на основі психо-емоційного впливу обраної діяльності в цілому та кожного із гіпотетично отриманих результатів окремо.

Оскільки критичне мислення вже є високо оціненим показником формування зрілої та високо функціональної особистості та став основою для розвитку методичного впровадження нових засобів та прийомів навчання, буде доцільно формувати цей навик на основі розвиненого емоційного інтелекту. Усе це не лише підвищить рівень володіння критичним мисленням, але й забезпечить формування ряду допоміжних навичок та розвине здібності, що є невід'ємними складовими частинами роботи майбутнього фахівця [12].

Висновки. Рівень якості підготовки спеціалістів визначається, поряд 3 іншими складовими професіоналізму, рівнем їхнього емоційного інтелекту, емоційною готовністю до професійної діяльності, яка забезпечує ефективне включення їх в активну діяльність, виступає умовою творчості, створення нового, самовдосконалення, швидкої адаптації до професійно зумовлених змін. Суттєве значення має емоційний інтелект у розвитку професійної самосвідомості студентів, що завжди є результатом емоційних переживань в єдності з самопізнанням у професійній діяльності і що забезпечує певний рівень їх професіоналізму. Необхідність розвитку емоційного інтелекту зумовлена також тим, що у фахівця мусить бути добре розвинена здатність до рефлексії як результату здатності розуміти власні емоції та емоції інших, що дає можливість об'єктивно оцінювати себе та інших у процесі професійної діяльності, виявляти внутрішньо особистісні та міжособистісні суперечності, шукати шляхи їх усунення, вибудовувати концепції професійного розвитку та стратегіï їі реалізації. Високорозвинений емоційний інтелект фахівця є основою розв'язання конфліктних ситуацій у процесі професійної діяльності, що виникають через наявність проблем, пов'язаних із виконанням професійно важливих завдань та особливостями взаємостосунків. 


\section{ЛITЕРАТУРА}

1. Гарднер Г. Множинні інтелекти. Теорія у практиці. Хрестоматія. Київ : Мегатайп, 2004. 288 с.

2. Гейвин Х. Когнитивная психология. Санкт-Петербург : Питер, 2003. 272 с.

3. Гілфорд Й.П. Природа людського інтелекту. Нью-Йорк : Мак-Гав Хілл. 1967. С. 86-139.

4. Готсдинер А.Л. К проблеме многосторонних способностей. Вопросы психологии. Москва, 1991. № 4. C. 82-87.

5. Гуревич П.С. Проти сервільності розуму. Філософія і культура. 2010. № 3. С. 106-107.

6. Гусерль Е. Філософія як строга наука. Новочеркаськ. 1994. 246 с.

7. Денієль М.Ф., Ауріек І. Філософія, критичне мислення та філософія для дітей. Освітня філософія та теорія. № 43(5). 2010. С. 415-435.

8. Джоунс Х. Ідеї з навчання мисленню: Сприймання учасників із спільною культурою мислительних навичок у освіті. Корікюлам джсорнал. № 19(4). 2008. С. 309-324.

9. Дружинін В.Н. Психологія загальних здібностей. Санкт-Петербург : Пітер. 2007. С. 29-30.

10. Зінченко В., Пружинин Б., Щедріна Т. Витоки культурно-історичної психології: філософсько-гуманітарний контекст. Москва, 2010.

11. Кант I. Сбр. твр.: в 8 т. 1994. Т. 4. С. 34, 236, 340.

12. Ліпман М. Мислення в освіті. Київ : Кембрідж юніверсіті прес, 1991. 188 с.

13. Ліпман М., Шарп А. М. та Осканян Ф. Філософія у класі. Ф.: Темпл юніверсіті прес. 1980. С. 188.

14. Маєр Дж. Д., Соловей П., Карусо Д. Р. Моделі емоційного інтелекту. Практикум з інтелекту. за ред. Стенберг Р. Нью-Йорк : Кембрідж юніверсіті прес. 2000. С. 396-420.

15. Нардон С. Ф., Лі Р. Г. Критичний міждисциплінний огляд: Стратегії студентоорієнтованої постановки проблемних питань. Коледж тічінг. № 59. 2011. С. 13-22.

16. Руднєв В.П. Поліфонічне тіло. Реальність і шизофренія в культурі ХХ століття. Москва, 2010. С. 20.

17. Шпет Г. Філософія і наука. Лекційні курси. Москва, 2010. С. 34.

18. Терно С. Критичне мислення - сучасний вимір суспільствознавчої освіти. Запоріжжя : Просвіта, 2009. $268 \mathrm{c}$.

19. Чошанов М. ТМИ - теория множественности интеллекта. Директор школи. Україна. Київ, 2000. № 3. С. $82-88$.

20. Фрідмен Д. Б., Крюз Т. Б., Кайседо Дж. М., Беслі ДЖ. С., Вейнберг Дж. та Фрімен М. Л. Введення в залучення до освіти використанням мультидисциплінарної групи вищого навчального закладу. Вища освіта. № 59. 2010. С. 765-783.

21. Хавасі Р. Е. Д. Отримуючи підказку. Едісон вік. № 21. 2001. С. 49.

\section{REFERENCES}

1. Hardner G. (2004) Mnoghunny intelectu. Teoriya y praktuci [Multiple minds. Theory in practice]. Kyiv: Magatype. (in Ukrainian)

2. Heyven H. (2003) Kognituvna psychologia [Cognetive psychology]. SP. : Piter. (in Russion)

3. Guilford Y. P. (1967) Priroda ludskogo intelektu [The nature of human intelligence]. N. Y. : Mc-Gaw Hill. (in Ukrainian)

4. Gotsdiner A. L. (1991) K problem mnogostoronnih sposobnostey [To the question of diverse skills]. Psychology questions, no. 4, pp. 82-87.

5. Gurevich P. S. (2010) Protu servilnosty rozumu [Against the service minding]. Phylosophy and culture, no. 3, pp. $106-107$.

6. Guserly E. (1994) Philosophia yak stroga nauka [Philosophy as a strict science]. Novocherkask. (in Ukrainian)

7. Daniel, M-F. \& Auriac, E. (2011) Filosofia, krutuchne muslenia ta filosofia dlia ditey [Philosophy, critical thinking and philosophy for children]. Educational Philosophy and Theory, vol. 5, no. 43, pp.415-435.

8. Jones, H. (2008) Idei z navchannia muslenniy: Spruimannia ychastnukiv iz spilnoiyu kulturoyu muslenievuh navuchok y osviti [Thoughts on teaching thinking: Perceptions of practitioners with a shared culture of thinking skills education]. The Curriculum Journal, vol. 4, no. 19, p. 309-324.

9. Drushunin V. N. (2007) Phychologia zagalnuh zdibnostey [General skills psychology]. SP: Piter. (in Ukrainian).

10. Zinchenko V., Pryshinin B., Shedrina T. (2010) Vutoky kulturno-istoruchnoy psikhologyi: philosofskogymanitarnuy kontekst [The origins of cultural and historical psychology: philosophy and humanity background]. Moskow. (in Ukrainian)

11. Kant I. (1994) Zbirka tvoriv [Text collection]. vol. 4, pp. 34, 236, 340. (in Ukrainian) 
12. Lipman M. (1991) Muslenia v osviti [Thinking in education]. Cambridge: Cambridge university press. (in Ukrainian)

13. Lipman, M., Sharp, A.M., \& Oscanyan, F. (1980) Filosofia y klasi [Philosophy in the classroom]. Philadelphia, PA: Temple University Press. (in Ukrainian)

14. Mayer J.D., Salovey P., Caruso D.R. (2000) Modeli emotsiynogo intelektu. Praktukum z intelektu [Models of emotional intelligence. [Handbook of intelligence] ed. by R.Stenberg]. N. Y. : Cambridge University Press. (in Ukrainian)

15. Nardone, C. F. \& Lee, R. G. (2011) Krutuchniy michdustsiplinniy ogliad: Strategii studentoorientovanoi postanovky problemnuh putan [Critical inquiry across the disciplines: Strategies for student-generated problem posing]. College Teaching, no. 59, pp. 13-22.

16. Rudnev V. P. (2010) Poliphonichne tilo. Realnist i schizophrenia v kultury XX stolittia [Poliphony body. Real and mania in XX century's culture]. Moskow. (in Ukrainian)

17. Shpet G. (2010) Philosophya i nayka. Lektsiyny kursu [Philosophy and science. Lecture course]. Moskow. (in Ukrainian)

18. Terno S. (2009). Krutuchne muslenia - suchasniy vumir suspilstvoznavchoi osvitu [Critical thinking modern way of social science]. Zaporizia: Prosvita. (in Ukrainian)

19. Choshanov M. (2000) Thoeriya Mnochunnosti intelektu [Multiple intelligence theory]. Durector skholu. Ukraina. no. 3, pp. 82-88.

20. Friedman, D. B., Crews, T. B., Caicedo, J. M., Besley, J. C., Weinberg, J., \& Freeman, M. L. (2010) Vvedenia v zaluchenia do osvity vukoristaniam multidustsiplinarnoi grupu vuchogo navchalnogo zakladu [An exploration into inquiry-based learning by a multidisciplinary group of higher education faculty]. Higher Education, no. 59, pp. 765-783.

21. Havasy, R.A.D. (2001) Otrumuyuchi pidkazku [Getting a clue]. Education Week. no. 21, p. 49. 